\title{
Labour Productivity in the Sustainable Development of Wood-based Industry: A Case for the European Union Countries
}

\author{
Emilia Grzegorzewska ${ }^{a}$ and Mariana Sedliačiková ${ }^{b, *}$ \\ Labour productivity is one of the key factors determining the wood-based \\ industry development and competitiveness. This study assessed the \\ importance of human resources and labour productivity in the furniture \\ sector in the European Union (EU) countries. A cluster analysis and \\ multivariate linear ordering analysis were conducted. The EU15, \\ especially Germany, Denmark, and United Kingdom, demonstrate a \\ higher labour productivity and offer even four-fold higher wages to the \\ employees than some EU13 countries. It results in a relatively high share \\ of labour costs in the production. However, in some countries of Central \\ and Eastern Europe, the importance of furniture production for the national \\ economy and the job market was high. To maintain the sustainable \\ development of the EU market, decreasing the regional differences is \\ essential. Additionally, the existing competitive advantage of selected \\ EU13 countries resulting from relatively low labour costs can be \\ insufficient to maintain the current rate of production growth and furniture \\ exports. The results of the study provide a precious source of information \\ for entrepreneurs, managers, and government. They will help the \\ production enterprises identify the areas to be made more efficient by \\ taking important decisions to enhance competitiveness and design the \\ future path of sustainable furniture sector development.
}

Keywords: Labour productivity; Employment; European Union countries; Wood-based industry; Cluster analysis; Hellwig's method

Contact information: a: Department of Technology and Entrepreneurship in Wood Industry, Institute of Wood Science and Furniture, University of Life Sciences - SGGW, 159 Nowoursynowska St., 02-776 Warsaw, Poland; b: Faculty of Wood Sciences and Technology, Technical University in Zvolen, T. G. Masaryka 24, 96001 Zvolen, Slovakia; *Corresponding author: sedliacikova@tuzvo.sk

\section{INTRODUCTION}

An important part of the global economy is the wood-based sector, which covers wood, furniture, and pulp-and-paper industries (Malá et al. 2018). These industries are based on processing wood, which can be regarded as a domestic eco-material (Potkány et al. 2018). A constantly growing demand for wood products calls for a rational and economically justified usage of wood material. However, wood is renewable only over a long time, and the forest potential is limited (Verkaik and Nabuurs 2000; Karkkainen et al. 2014). Wood is the most abundant biodegradable material available and has excellent properties for reuse; hence, its use should be maximized (Daian and Ozarska 2009; Laleicke 2018; Malá et al. 2018). Thus, the sustainable development of the industry, factoring in the economic, social, and environmental aspects, is becoming of special importance. This approach coincides with the research of sustainable development of wood-based industry. According to Azizi et al. (2016), the wood processing industry seems to be significant not only from economical and social standpoints but also from the 
perspective of environmentally compatible industries. With the current eco-challenges, it is also important to maintain the equilibrium of socioeconomic activity of present and future generations. Especially in sectors based on limited natural resources, there is a necessity to pay more attention to the needs of the developing industry at the same time as considering environmental issues.

Various wood-based materials are used to produce furniture. In the years 2003 to 2017, the value of the global furniture production increased from USD 223 billion to USD 450 billion. Over just 15 years the furniture production doubled, and over the last 10 years it has grown by over 60\% (Jivkov 2019). For years the largest furniture manufacturers have been China, the USA, Germany, India, Italy, and Poland (Han et al. 2009; Grzegorzewska and Stasiak-Betlejewska 2014; Grzegorzewska and Więckowska 2016; Halaj et al. 2018).

Due to the complexity of the economic processes and a progressing market integration, a growing competition pressure, to a smaller or greater extent, applies to each business. Searching for new sources of competitive advantage corresponding to the production resources available and the existing experience is one of the essential market challenges. One of the elements determining the economic competitiveness of its respective sectors is the production factor effectiveness. This element also applies to the wood-based sector, which is a labour-intensive industry (Maskell 1998; Jelačić et al. 2020).

Productivity is measured as a relation of production to the inputs (Rogers 1998; Owyong 2000; Song and AbouRizk 2008; Hall 2011). The basic productivity indicators cover labour and capital productivity. Labour is one of the most important production factors because the qualifications and loyalty of the labour force are the basic success elements in any industrial sector (Neykov et al. 2017). The labour productivity, as the most common indicator for measuring the productivity, is the output corresponding to the workforce-generated input (Lieberman and Kang 2008). The labour productivity affects the cost, profitability, and competitiveness of products (Bozsik and Magda 2018).

The factors determining labour productivity and a general economic development of a given country include demographic indicators and the features of the residents of that country (Murphy et al. 1991; Feyrer 2008; Van Dalen et al. 2010), as well as the labour force education level (Barro 1991; Krueger and Lindhal 2001). The countries with a considerable share of employees with basic skills record a lower labour productivity and a lower economic growth than those where the employees' qualifications are high. Additionally, a low-qualified labour force can be a negative factor for labour productivity. A discrepancy between the objectives of the employment policy and lowering the unemployment in respective countries and labour productivity can be lowered if the employees' skills increase.

The studies of employment and labour productivity also concern the wood-based industry. For example, Neykov et al. (2017) investigated the factors affecting the level of employment, especially production, prices, and investments in tangible goods in the Bulgarian, Macedonian, and Romanian wood-based and furniture industry. Ratnasingam et al. (2017) assessed the productivity performance of six major timber sub-sectors in Malaysia: joinery wood products, particleboard and fibreboard, wooden and cane furniture, sawmilling of wood, veneer sheet and plywood, and builders' joinery and carpentry. They emphasized that labour productivity within the timber sector is stagnant and has affected the capital use. Employment and labour productivity in the woodworking industry have also been studied by other authors (Merková and Drabek 2010; Burja and Mărginean 2013; Pang et al. 2015; Chobanova and Georgieva 2017; Neykov et al. 2018; Grzegorzewska et al. 2020). Motivation and its factors are important aspects in determining the labour-force 
quality (Lorincová et al. 2016; Hitka et al. 2017, 2019). In addition, the labour productivity of the wood-based industry depends also on the level of plant technical equipment, the technologies applied, production innovativeness (Smardzewski 2009), and the quality of human resources (Hitka and Sirotiakovà 2011). The role of innovation activities and capital expenditure that contribute to technical progress and production efficiency are increasingly emphasized (Ratnasingam and Ioras 2009; Popyk et al. 2014; Bumgardner et al. 2016; Ratnasingam et al. 2017; Neykov et al. 2019). The development of the furniture industry is positively influenced by investment expenditure related to technological progress and innovations, which is conducive to labour productivity and, consequently, also to an increase in wages and an improvement in the quality of the labour factor in this industry. In manufacturing companies, also in wood-based industries, capital expenditures mainly concern the acquisition, maintenance, and upgrade of fixed assets, especially machinery and equipment. However, according to Panytin et al. (2020), the investment attractiveness of the wood-based industry is still not so high as is necessary for the branch.

Currently, more attention is also being paid to the automation and digitization of production processes and their importance for increasing labour productivity, as well as reducing unit production costs. Research in this area also concern the wood-based industry. Ratnasingam et al. (2019) emphasized that most responsive towards the adoption of automated technologies were the panel-based, plastic, and metal furniture manufacturers. Among the more important motives for the use of automated technologies, Malaysian furniture manufacturers mentioned lower unit cost and higher output. In addition, consistent quality, standardized components, and higher productivity were indicated. Automation is driven primarily by higher production capacity, cost, product characteristics, and government policy, which inevitably underscores the cost-sensitive nature of the industry. Similarly, Ratnasingam et al. (2020) investigated that the main reasons for acquiring automated technologies were to improve productivity, reduce workforce, reduce cost, and improve quality. Salim et al. (2016) emphasized increased profitability and competitiveness. The importance of production automation and new technologies for the wood-based industry was also mentioned by Wu (2016), Landscheidt and Kans (2016), Wang et al. (2017), and Landscheidt et al. (2017). Wood product industries are traditionally slow in development and adaption to new machinery, flexible automation, and computerization (Landscheidt and Kans 2016). Although the awareness of the Industry 4.0 concept and the number of implementations of its elements are growing in wood-based enterprises, especially large and medium-sized, as indicated by Ratnasingam et al. (2019) some furniture companies are not quite ready to implement this concept. Larger enterprises may be financially stronger and have much greater opportunities to invest in new technologies (Dangayach and Deshmukh 2005; Horváth and Szabó 2019). Still, the competences and skills of engineers do not fully meet the increasingly higher requirements imposed by dynamic changes resulting from the industrial revolution 4.0.

The research results provided are an important contribution to the process of evaluating the employment structure and labour productivity in wood-based industry. However, when facing a dynamically changing environment and a growing role of sustainable development, those considerations must be supplemented, especially with international comparisons of labour productivity in the industry based on renewable and limited wood material. Due to the importance of the wood-based industry and essential role of the European Union (EU) in the global economy, there is a need for further studies of production factor effectiveness, including labour productivity. Thus, the objective of this study is to assess the importance of employment and labour productivity in the furniture 
sector in the EU member states, indicating a group of countries with some similarity in terms of selected economic-production features related to employment and labour productivity and determining the position of respective countries on the EU market based on those diagnostic variables.

The following hypothesis and research questions were formulated regarding the purpose of the research:

Hypothesis: The new member states of the European Union (EU 13) show relatively lower labour productivity in the furniture manufacturing industry than the EU 15 countries.

RQ1: Which EU countries are similar in terms of labour productivity in the furniture manufacturing industry?

$R Q 2$ : What factors may determine the level of employment and labour productivity in the furniture manufacturing industry in the EU countries?

The structure of this paper is as follows. In the introduction, the goals, as well as the description of research are briefly outlined. In addition, the methodology of the research (cluster analysis and Hellwig's method) and its results are described. The limitations of the conducted analyses and proposals for further research on labour productivity in the furniture industry were also indicated. The conclusion sums up the findings and recommendations of the research.

\section{EXPERIMENTAL}

\section{Materials}

The key source of statistics has been the Eurostat-Annual detailed enterprise statistics for industry (sbs_na_ind_r2). The studies covered furniture production, which is part of the wood-based industry. The furniture industry in NACE (Nomenclature statistique des Activités économiques dans la Communauté Européenne) classification Revision 2 represents section C31 Furniture production. The analysis covers the 2010-2016 period, as for that period complete and credible statistics were acquired. However, the analysis excluded Ireland due to missing long-term data. The employment and labour-productivity details were acquired separately for each year covered by the analysis. The database considering the indicators for the entire period was developed.

\section{Methods}

A cluster analysis was performed with k-means to identify which of the objects analysed (EU countries) are most related to each other in terms of the criteria identified for employment and labour productivity.

To select the economic-production indicators, the applicable literature (Bervidová 2002; Syverson 2010; Gumerov et al. 2020; Herman 2020) and the completeness of data in the Eurostat database were considered. Moreover, the selected indicators should be related to labour productivity in the furniture industry. The Eurostat database was selected because it contains comparable statistical data from European Union countries.

The following indicators were covered: the share of the employees in the furniture industry in the total industry (\%), the number of employees per enterprise (number of persons), the furniture production sold per employee (EUR), the annual wages per employee (EUR), the share of labour costs in production (\%), and the furniture production sold for every 1000 euro of the labour costs (EUR). Table 1 presents the definitions of the labour and work productivity indicators analysed in the research. 
Table 1. Definitions of the Labour and Work Productivity Indicators

\begin{tabular}{|c|c|c|}
\hline $\begin{array}{c}\text { Indicators } \\
\begin{array}{c}\text { Share of the furniture industry employees } \\
\text { in the industry employment (\%) }\end{array}\end{array}$ & $\begin{array}{c}\text { Number of the employees } \\
\text { in the furniture industry }\end{array}$ & $\begin{array}{c}\text { Total number of industry } \\
\text { employees }\end{array}$ \\
\hline $\begin{array}{c}\text { Number of employees per enterprise } \\
\text { (persons) }\end{array}$ & $\begin{array}{c}\text { Number of the employees } \\
\text { in the furniture industry } \\
\text { (EUR) }\end{array}$ & $\begin{array}{c}\text { Number of furniture } \\
\text { enterprises }\end{array}$ \\
\hline $\begin{array}{c}\text { Furniture production sold per employee } \\
\text { Furniture production sold }\end{array}$ & $\begin{array}{c}\text { Number of furniture } \\
\text { industry employees }\end{array}$ \\
\hline $\begin{array}{c}\text { Shnual wages per employee (EUR) } \\
\text { Furniture production sold for every 1000 } \\
\text { euro of labour costs (EUR) }\end{array}$ & $\begin{array}{c}\text { Annual wages in the } \\
\text { furniture industry }\end{array}$ & $\begin{array}{c}\text { Number of furniture } \\
\text { industry employees }\end{array}$ \\
\hline \multicolumn{2}{|c|}{ Labour costs } & Production \\
\hline
\end{tabular}

The cluster analysis and the Hellwig's method were used to achieve the set goal of research on employment and labour productivity in furniture manufacturing industry.

\section{Cluster analysis}

Cluster analysis groups data objects based only on the information found in the data that describes the objects and their relationships (Tan et al. 2005). Clustering is a process in which a group of unlabelled patterns is partitioned into a number of sets, so that similar patterns are assigned to the same cluster, and dissimilar patterns are assigned to different clusters (Hung et al. 2005). K-means is a well-known partitional clustering method, widely adopted in science thanks to its easy implementation, simplicity and application efficiency (Han and Kamber 2006).

The objective of k-means clustering was to identify the group of EU countries similar in terms of selected employment aspects and labour productivity. Due to the diversified measuring scales of the variables, the procedure of their standardisation was implemented in order to normalise the measurement units as well as to eliminate the diversification of variables in terms of the location and variability of the studied population (Balicki 2009).

The first step of cluster analysis with k-means determined the number $\mathrm{K}$ of clusters that the observation set must be partitioned into. Then for each iteration, the vectors of means, the so-called centre of gravity (points determining the value from which in a similar distance the objects of the cluster are found), were calculated. Objects were classified into clusters by determining those median values. Each object $\mathrm{O}_{\mathrm{i}}(i=1, \ldots, n)$ was assigned to the group with the closest centre of gravity, the so-called $\mathrm{O}_{\mathrm{i}} \in \mathrm{S}_{\mathrm{j}}$, when $\mathrm{d}\left(\mathrm{O}_{\mathrm{i}}, \mathrm{M}_{\mathrm{j}}\right)=d\left(\mathrm{O}_{\mathrm{i}}\right.$, $\mathrm{M}_{\mathrm{j}}$ ), where $d$ is the Euclidean distance. A given object (country) has been classified to that cluster from the centre of which it was closest. In the successive iterations, attempts were made to assign the objects. It was possible as earlier no hierarchy of clusters was determined, and the objects could go from one group to another. It means that for $\mathrm{S}_{\mathrm{j}}(j=1$, $\ldots, k)$, new centres of gravity were calculated as arithmetic means of all the objects of a given group (Frątczak et al. 2009).

At the next research stage, there was applied a multivariate data analysis with the use of the method of linear ordering. Due to a wide spectrum of applications and universality for the evaluation of economic and social phenomena, the Hellwig's development model method was used. There was determined the variation of the features studied with the coefficient of variation. Further research assumed the features for which the coefficient of variation exceeded the value of 0.1 and, additionally, the features not 
strongly correlated, and below 0.7, were considered (Ratner 2009). In the analyses performed, the calculated coefficient of variation confirmed a sufficient level of variation for all the features which provide the grounds for building a synthetic measure.

Then of all the features studied, there were identified stimulants (the features the high values of which are desired, and the low ones are unwelcome) and destimulants (for which the opposite assumptions are made). The indicators were exposed to normalization, involving the assignment of adequately processed (transformed) variables to primary variables. To do so, the zero unitarization was used as it meets all the data normalization postulates. The diagnostic variables were transformed compliant with the following formulae (Kukuła 2014; Kukuła 2016),

For stimulants:

$$
z_{i j}=\frac{x_{i j}-\min _{i} x_{i j}}{\max _{i} x_{i j}-\min _{i} x_{i j}}
$$

For destimulants:

$$
z_{i j}=\frac{\max _{i} x_{i j}-x_{i j}}{\max _{i} x_{i j}-\min _{i} x_{i j}}
$$

where $z_{\mathrm{ij}}$ is the normalized value of the $j$ variable in the $i$ object, and $x_{i j}$ is the value of the $j$ diagnostic variable in the $i$ object.

There was determined an abstract object, the so-called development model $z_{0 j}$ with the best values for each variable, and the so-called anti-model with_oj with the worst values of each variable determined with the following relations (Stec 2011):

$$
\begin{aligned}
& \left\{\begin{array}{c}
z_{0 j}=\max z_{i j}, \quad \text { when } \mathrm{x}_{\mathrm{j}} \text { is a stimulant } \\
\text { or } \quad j=1,2, L, m \\
z_{0 j}=\min z_{i j},
\end{array}\right. \\
& \left\{\begin{array}{c}
z_{0 j}=\max z_{i j}, \quad \text { when } \mathrm{x}_{\mathrm{j}} \text { is a stimulant } \\
\qquad u b \quad j=1,2, L, m \\
z_{0 j}=\min z_{i j}, \text { when } \mathrm{x}_{\mathrm{j}} \text { is a destimulant }
\end{array}\right.
\end{aligned}
$$

The similarity of the objects was analysed against the abstract best object by calculating the Euclidean distance for each object from the development model (Balicki 2009),

$$
d_{i 0}=\sqrt{\sum_{j=1}^{p}\left(z_{i j}-z_{o j}\right)^{2}}
$$

For each object (country) there was determined the so-called development measure according to Eqs. 6 and 7,

$$
\begin{aligned}
& m_{i}=1-\frac{d_{i 0}}{d_{0}} \\
& d_{0}=\sqrt{\sum_{j=1}^{p}\left(z_{0 j}-z_{-0 j}\right)^{2}}
\end{aligned}
$$

where $m_{\mathrm{i}}$ is the measure of development for $i$-th object, and $d_{0}$ is the distance between the development model and the anti-model.

Values of Hellwig's development measures are contained in the range from 0 to 1 , 
save that the measure of development calculated for the model equals one, and for the antimodel - zero. A higher value of the development measure stands for a higher level of the complex phenomenon. With the values of the measure of development, the rankings were built separately for each year (2010 to 2016), and then the positions of the countries were averaged, which provided the grounds for developing the final breakdown for a given period. All the statistical analyses were performed with the SPSS Statistics 24.0 package. As for the study of the significance of diagnostic variables in the cluster analysis, the inference was made at the level of significance of $\alpha=0.05$.

\section{RESULTS AND DISCUSSION}

The analysis of clusters of k-means was performed for all EU countries. The preliminary analysis demonstrated that for three centres of clusters, the convergence in cluster centres was reached after five iterations. While adding the centres of clusters, it turned out that iteration stops at the third level for six clusters. The first centre included Estonia and Lithuania, the second one - Belgium, Sweden, United Kingdom, and Italy, while the third one - Denmark and Germany. The fourth cluster covered seven countries; Bulgaria, the Czech Republic, Latvia, Poland, Romania, Slovakia, and Hungary. The fifth cluster included five countries - Austria, Finland, France, Luxembourg, and Netherlands, and the sixth cluster - Greece, Spain, Croatia, Cyprus, Malta, and Slovenia. The recapitulation for respective countries representing specific centres is presented in Table 2.

Table 2. Assignment of the Countries to Respective Cluster Centres

\begin{tabular}{|l|c|c|l|c|c|l|c|c|}
\hline Country & Cluster & Distance & \multicolumn{1}{|c|}{ Country } & Cluster & Distance & Country & Cluster & Distance \\
\hline Estonia & 1 & 1.285 & Bulgaria & 4 & 1.512 & France & 5 & 1.052 \\
\hline Lithuania & 1 & 1.285 & Czech Republic & 4 & 1.726 & Luxembourg & 5 & 1.771 \\
\hline Belgium & 2 & 1.445 & Latvia & 4 & 1.028 & Netherlands & 5 & 1.344 \\
\hline Sweden & 2 & 1.505 & Poland & 4 & 1.379 & Greece & 6 & 0.834 \\
\hline $\begin{array}{l}\text { United } \\
\text { Kingdom }\end{array}$ & 2 & 1.583 & Romania & 4 & 2.025 & Spain & 6 & 1.233 \\
\hline Italy & 2 & 1.148 & Slovakia & 4 & 1.560 & Croatia & 6 & 1.551 \\
\hline Denmark & 3 & 1.178 & Hungary & 4 & 1.224 & Cyprus & 6 & 1.331 \\
\hline Germany & 3 & 1.178 & Austria & 5 & 1.362 & Malta & 6 & 1.570 \\
\hline Portugal & 4 & 1.470 & Finland & 5 & 1.096 & Slovenia & 6 & 0.615 \\
\hline
\end{tabular}

Due to the varied measurement scales of diagnostic variables, their normalization procedure was applied to standardize the measurement units and to eliminate a variation in variables in terms of position and variation of the population studied. The results of the analysis of variance for diagnostic variables are presented in Table 3.

The analysis of variance demonstrated that the strongest diagnostic variables were the furniture production sold per employee $(\mathrm{F}=34.047 ; \mathrm{p}<0.001)$, and the annual wages per employee $(\mathrm{F}=33.619 ; \mathrm{p}<0.001)$. The other variables, namely the furniture production sold for every 1000 euro of labour costs $(\mathrm{F}=8.476$; $\mathrm{p}<0.001)$, the share of labour costs in production $(\mathrm{F}=7.806 ; \mathrm{p}<0.001)$, the share of employees in the furniture industry to the number of industry employees in total $(\mathrm{F}=7.630 ; \mathrm{p}<.0001)$, and the number of employees per enterprise $(\mathrm{F}=5.582 ; \mathrm{p}<0.002)$, showed a lower diagnostic power. A variable number of employees turned out not to be a good diagnostic variable. 
Table 3. Results of the Analysis of Variance for Diagnostic Variables

\begin{tabular}{|c|c|c|c|c|c|c|}
\hline \multirow{2}{*}{ Specification } & \multicolumn{2}{|c|}{ Cluster } & \multicolumn{2}{c|}{ Error } & \multirow{2}{*}{ F } & Significance \\
\cline { 2 - 6 } & $\begin{array}{c}\text { Mean } \\
\text { square }\end{array}$ & df & $\begin{array}{c}\text { Mean } \\
\text { square }\end{array}$ & df & & \\
\hline Number of employees & 0.046 & 5 & 0.048 & 20 & 0.945 & $<0.474$ \\
\hline $\begin{array}{c}\text { Share of employees in the } \\
\text { furniture industry to the number } \\
\text { of industry employees in total } \\
(\%)\end{array}$ & 3.792 & 5 & 0.497 & 20 & 7.630 & $<0.001$ \\
\hline $\begin{array}{c}\text { Number of employees per } \\
\text { enterprise (number of persons) }\end{array}$ & 3.215 & 5 & 0.576 & 20 & 5.582 & $<0.002$ \\
\hline $\begin{array}{c}\text { Furniture production sold per } \\
\text { employee (EUR) }\end{array}$ & 4.746 & 5 & 0.139 & 20 & 34.047 & $<0.001$ \\
\hline $\begin{array}{c}\text { Annual wages per employee } \\
\text { (EUR) }\end{array}$ & 4.525 & 5 & 0.135 & 20 & 33.619 & $<0.001$ \\
\hline $\begin{array}{c}\text { Share of labour costs in } \\
\text { production (\%) }\end{array}$ & 3.834 & 5 & 0.491 & 20 & 7.806 & $<0.001$ \\
\hline $\begin{array}{c}\text { Furniture production sold for } \\
\text { every 1000 euro of labour costs } \\
\text { (EUR) }\end{array}$ & 3.695 & 5 & 0.436 & 20 & 8.476 & $<0.001$ \\
\hline
\end{tabular}

Table 4 presents intraclass means (mean values of each variable for countries that are classified in the same cluster) of the selected diagnostic variables characteristic for the employment and labour productivity in the furniture manufacturing industry in the EU countries.

Table 4. Intraclass Means of Selected Variables for Employment and Labour Productivity in the EU Countries

\begin{tabular}{|c|c|c|c|c|c|c|}
\hline \multirow{2}{*}{ Itemisation } & \multicolumn{6}{|c|}{ Cluster } \\
\cline { 2 - 7 } & 1 & 2 & 3 & 4 & 5 & 6 \\
\hline Number of employees & 15450.10 & 64931.80 & 76416.85 & 42679.64 & 23364.88 & 17523.25 \\
\hline $\begin{array}{c}\text { Share of furniture } \\
\text { industry employees in } \\
\text { the total number of } \\
\text { industry employees (\%) }\end{array}$ & 9.65 & 3.05 & 2.55 & 4.29 & 2.35 & 4.20 \\
\hline $\begin{array}{c}\text { Number of employees } \\
\text { per enterprise (number } \\
\text { of persons) }\end{array}$ & 14.35 & 8.60 & 19.80 & 10.03 & 6.88 & 5.27 \\
\hline $\begin{array}{c}\text { Furniture production sold } \\
\text { per employee (EUR) }\end{array}$ & 48250.55 & 142360.48 & 153716.35 & 36752.29 & 113228.35 & 48271.46 \\
\hline $\begin{array}{c}\text { Annual wages per } \\
\text { employee (EUR) }\end{array}$ & 7268.70 & 24051.38 & 35022.05 & 5745.99 & 27809.85 & 11373.13 \\
\hline $\begin{array}{c}\text { Share of labour costs in } \\
\text { production (\%) }\end{array}$ & 19.90 & 22.98 & 26.15 & 18.60 & 31.33 & 27.87 \\
\hline $\begin{array}{c}\text { Furniture production sold } \\
\text { for every 1000 euro of } \\
\text { labour costs (EUR) }\end{array}$ & 5014.70 & 3849.81 & 3653.87 & 4779.45 & 2984.36 & 2738.86 \\
\hline
\end{tabular}

The first cluster included Lithuania and Estonia. This cluster showed the highest share of employees in the furniture industry in the total number of industry employees (almost every $10^{\text {th }}$ person working in industry was employed in furniture manufacture enterprises), as well as a relatively high number of employees per enterprise. Even though 
the mean number of employees in those countries was one of the lowest, however, it involved a relatively lower number of enterprises. Those countries recorded a relatively low economic labour productivity, which is evident from the value below the mean value of furniture industry production per employee. Besides, there were noted low level annual wages and additionally relatively low the share of the labour costs in production; lower labour costs than EU average.

The second cluster which included four countries (Belgium, Sweden, United Kingdom, and Italy) showed a higher number of employees than the first cluster. However, the furniture industry in those countries was not such an important employer as in Lithuania and in Estonia. The share of employees in that industry in the total number of industry employees was more than three-fold lower than in the first cluster. The cluster showed a relatively high labour productivity, which is evident from the high value of production sold per employee, which was more than $50 \%$ higher than the average value in the EU countries and $20 \%$ higher than the average in the old EU countries. Besides, the cluster showed higher labour costs; the annual wages per employee were more than $40 \%$ higher than the average in the EU and as much as four-fold higher than in the EU13 countries. It resulted in a higher share of labour costs in production.

The third cluster included only two countries, Denmark and Germany. Those countries recorded a relatively low share of employees in the furniture industry as compared with the total number of employees in industry; however, the number of employees per enterprise was highest of all the clusters identified. The wages in those countries were highest; more than two-fold higher than the EU average and almost six-fold higher than the EU13 average. Interestingly, those countries recorded a high labour productivity. One employee in the furniture industry generated $30 \%$ higher production value than the EU average and as much as four-fold higher than in the EU13 countries. However, high labour costs resulted in their high share in production costs, and they translated into a lower value of that production for every 1000 euro of labour costs.

Another cluster covered 8 countries. Next to Portugal, it included as many as 7 countries representing new EU members (Bulgaria, the Czech Republic, Latvia, Poland, Romania, Slovakia, Hungary). The cluster recorded a relatively high, more than two-fold higher that the EU average, share of employees in the furniture industry, which confirmed an important role of that industry as the employer in various countries. The employees' wages were lowest, almost three-fold lower that the EU average. It resulted in a lower share of labour costs in production. Labour productivity in that cluster was lower; one employee generated, on average, two-and-a-half-times lower furniture production value sold than the EU average and more than three times lower value of that production than the EU average in the old member countries.

The fifth cluster included five old EU member countries (Austria, Finland, France, Luxembourg, and Netherlands). The cluster recorded, on average, the lowest share of furniture industry employees in the total number of employees in industry. Similarly, the number of employees per enterprise was also low. However, the wages per employee were relatively favourable; more than two-and-a-half higher than the EU average and more than four-time higher than in the EU13 countries. That cluster recorded a relatively high labour productivity measured with the value of the furniture production sold per employee, however, the second and the third clusters noted higher values. On top of that, the fifth cluster countries reported high wages and a considerable share of labour costs in production. Therefore, translating the production value for every 1000 euro of labour costs identified that in the countries with higher wages the value is lower than in the EU13 
countries and in the clusters where the costs are lower.

The last cluster included Greece, Spain, Croatia, Cyprus, Malta, and Slovenia, showing the share of furniture industry employees in the total number of industry employees similar to the EU average and the lowest number of employees per enterprise. The number of furniture industry employees in those countries was one of the lowest. The annual wages per employee were low, as compared with the clusters with the old EU member states; and as compared with the third cluster - almost three-fold lower. Those countries recorded a relatively low labour productivity, evident from the value below the furniture industry production average per employee. Besides, there were noted low annual wages and, additionally, a relatively low share of labour costs in production, which points to lower than the EU average labour costs.

The second stage of the study analysed the position of the EU countries in terms of labour productivity in the furniture industry. Table 5 presents the values of the measure of Hellwig's development model for EU countries and Table 6 shows standing of these countries in Hellwig's ranking.

Table 5. Values of the Measure of Hellwig's Development Model for Respective Countries in 2010-2016

\begin{tabular}{|c|c|c|c|c|c|c|c|c|c|c|}
\hline Country & 2010 & 2011 & 2012 & 2013 & 2014 & 2015 & 2016 & Mean & $\mathrm{SD}^{*}$ & $\mathrm{~V}^{* *}$ \\
\hline Austria & 0.382 & 0.397 & 0.417 & 0.413 & 0.390 & 0.384 & 0.390 & 0.396 & 0.014 & 3.45 \\
\hline Belgium & 0.345 & 0.356 & 0.366 & 0.377 & 0.360 & 0.350 & 0.367 & 0.360 & 0.011 & 3.03 \\
\hline Bulgaria & 0.152 & 0.169 & 0.160 & 0.164 & 0.162 & 0.161 & 0.158 & 0.161 & 0.005 & 3.10 \\
\hline Croatia & 0.233 & 0.238 & 0.230 & 0.229 & 0.217 & 0.214 & 0.214 & 0.225 & 0.010 & 4.35 \\
\hline Cyprus & 0.248 & 0.243 & 0.239 & 0.218 & 0.188 & 0.187 & 0.163 & 0.212 & 0.033 & 15.51 \\
\hline Czech Republic & 0.196 & 0.189 & 0.186 & 0.179 & 0.170 & 0.167 & 0.168 & 0.179 & 0.011 & 6.39 \\
\hline Denmark & 0.489 & 0.493 & 0.485 & 0.481 & 0.468 & 0.466 & 0.468 & 0.479 & 0.011 & 2.33 \\
\hline Estonia & 0.259 & 0.286 & 0.290 & 0.290 & 0.291 & 0.293 & 0.293 & 0.286 & 0.012 & 4.25 \\
\hline Finland & 0.335 & 0.360 & 0.377 & 0.379 & 0.360 & 0.360 & 0.363 & 0.362 & 0.014 & 3.97 \\
\hline France & 0.400 & 0.365 & 0.382 & 0.379 & 0.360 & 0.383 & 0.377 & 0.378 & 0.013 & 3.45 \\
\hline Germany & 0.499 & 0.517 & 0.525 & 0.529 & 0.512 & 0.499 & 0.507 & 0.513 & 0.012 & 2.31 \\
\hline Greece & 0.231 & 0.220 & 0.218 & 0.196 & 0.166 & 0.160 & 0.131 & 0.189 & 0.037 & 19.78 \\
\hline Hungary & 0.182 & 0.186 & 0.183 & 0.185 & 0.181 & 0.178 & 0.175 & 0.182 & 0.004 & 2.08 \\
\hline Italy & 0.414 & 0.440 & 0.450 & 0.437 & 0.428 & 0.430 & 0.427 & 0.432 & 0.011 & 2.60 \\
\hline Latvia & 0.204 & 0.207 & 0.201 & 0.201 & 0.204 & 0.209 & 0.205 & 0.204 & 0.003 & 1.34 \\
\hline Lithuania & 0.258 & 0.293 & 0.298 & 0.292 & 0.294 & 0.294 & 0.285 & 0.288 & 0.014 & 4.81 \\
\hline Luxembourg & 0.283 & 0.285 & 0.308 & 0.302 & 0.291 & 0.300 & 0.301 & 0.296 & 0.009 & 3.18 \\
\hline Malta & 0.187 & 0.161 & 0.156 & 0.126 & 0.142 & 0.138 & 0.142 & 0.150 & 0.020 & 13.22 \\
\hline Netherlands & 0.357 & 0.358 & 0.368 & 0.362 & 0.325 & 0.323 & 0.324 & 0.345 & 0.020 & 5.89 \\
\hline Poland & 0.282 & 0.325 & 0.319 & 0.311 & 0.309 & 0.317 & 0.314 & 0.311 & 0.014 & 4.41 \\
\hline Portugal & 0.245 & 0.257 & 0.255 & 0.244 & 0.235 & 0.238 & 0.240 & 0.245 & 0.008 & 3.40 \\
\hline Romania & 0.237 & 0.264 & 0.263 & 0.256 & 0.256 & 0.257 & 0.251 & 0.255 & 0.009 & 3.56 \\
\hline Slovakia & 0.284 & 0.233 & 0.234 & 0.241 & 0.231 & 0.243 & 0.250 & 0.245 & 0.018 & 7.46 \\
\hline Slovenia & 0.262 & 0.271 & 0.268 & 0.247 & 0.226 & 0.232 & 0.232 & 0.248 & 0.019 & 7.60 \\
\hline Spain & 0.369 & 0.372 & 0.375 & 0.348 & 0.316 & 0.309 & 0.312 & 0.343 & 0.030 & 8.76 \\
\hline Sweden & 0.361 & 0.391 & 0.401 & 0.405 & 0.390 & 0.382 & 0.383 & 0.388 & 0.014 & 3.73 \\
\hline United Kingdom & 0.387 & 0.433 & 0.438 & 0.446 & 0.431 & 0.466 & 0.486 & 0.441 & 0.031 & 7.04 \\
\hline
\end{tabular}

${ }^{*} \mathrm{SD}$ - standard deviation

${ }^{* *} \mathrm{~V}-$ coefficient of variation 
The breakdown leader for the entire period covered by the analysis was Germany and, additionally, the measure of Hellwig's development model increased from 0.499 to 0.507. It means that, on average, the standing of the German furniture industry in terms of employment and labour productivity improved. The German economy came third in terms of the number of furniture industry entities; however, that industry was not such an important employer for the total number of the industry employees as in the smaller UE13 countries. Interestingly, the number of employees per enterprise was relatively high, however, in the period studied the value decreased, which was due to a greater rate of increase in the number of enterprises that the number of employees (62 against 6\%). The German economy recorded relatively high values of furniture production per employee and, additionally, relatively high wages per employee.

Table 6. Standing of the EU Countries in Hellwig's Ranking in 2010-2016

\begin{tabular}{|l|c|c|c|c|c|c|c|c|c|}
\hline \multicolumn{1}{|c|}{ Country } & 2010 & 2011 & 2012 & 2013 & 2014 & 2015 & 2016 & Mean & Change \\
\hline Austria & 6 & 5 & 5 & 5 & 6 & 5 & 5 & 5 & -1 \\
\hline Belgium & 10 & 11 & 11 & 9 & 7 & 9 & 8 & 9 & -2 \\
\hline Bulgaria & 27 & 26 & 26 & 26 & 26 & 25 & 25 & 26 & -2 \\
\hline Croatia & 21 & 20 & 21 & 20 & 20 & 20 & 20 & 20 & -1 \\
\hline Cyprus & 18 & 19 & 19 & 21 & 22 & 22 & 24 & 21 & 6 \\
\hline Czech Republic & 24 & 24 & 24 & 25 & 24 & 24 & 23 & 25 & -1 \\
\hline Denmark & 2 & 2 & 2 & 2 & 2 & 3 & 3 & 2 & 1 \\
\hline Estonia & 16 & 14 & 15 & 15 & 14 & 15 & 14 & 15 & -2 \\
\hline Finland & 11 & 9 & 8 & 8 & 8 & 8 & 9 & 8 & -2 \\
\hline France & 4 & 8 & 7 & 7 & 9 & 6 & 7 & 7 & 3 \\
\hline Germany & 1 & 1 & 1 & 1 & 1 & 1 & 1 & 1 & 0 \\
\hline Greece & 22 & 22 & 22 & 23 & 25 & 26 & 27 & 23 & 5 \\
\hline Hungary & 26 & 25 & 25 & 24 & 23 & 23 & 22 & 24 & -4 \\
\hline Italy & 3 & 3 & 3 & 4 & 4 & 4 & 4 & 4 & 1 \\
\hline Latvia & 23 & 23 & 23 & 22 & 21 & 21 & 21 & 22 & -2 \\
\hline Lithuania & 17 & 13 & 14 & 14 & 13 & 14 & 15 & 14 & -2 \\
\hline Luxembourg & 13 & 15 & 13 & 13 & 15 & 13 & 13 & 13 & 0 \\
\hline Malta & 25 & 27 & 27 & 27 & 27 & 27 & 26 & 27 & 1 \\
\hline Netherlands & 9 & 10 & 10 & 10 & 10 & 10 & 10 & 10 & 1 \\
\hline Poland & 14 & 12 & 12 & 12 & 12 & 11 & 11 & 12 & -3 \\
\hline Portugal & 19 & 18 & 18 & 18 & 17 & 18 & 18 & 19 & -1 \\
\hline Romania & 20 & 17 & 17 & 16 & 16 & 16 & 16 & 16 & -4 \\
\hline Slovakia & 12 & 21 & 20 & 19 & 18 & 17 & 17 & 18 & 5 \\
\hline Slovenia & 15 & 16 & 16 & 17 & 19 & 19 & 19 & 17 & 4 \\
\hline Spain & 7 & 7 & 9 & 11 & 11 & 12 & 12 & 11 & 5 \\
\hline Sweden & 8 & 6 & 6 & 6 & 5 & 7 & 6 & 6 & -2 \\
\hline United Kingdom & 5 & 4 & 4 & 3 & 3 & 2 & 2 & 3 & -3 \\
\hline
\end{tabular}

The next country in the ranking was Denmark which, in the cluster analysis, represented the cluster together with Germany. Of all the EU countries, in the Danish furniture industry the employees' wages per employee were highest. The Danish economy recorded the highest labour productivity measured with the value of production per employee. The number of employees per enterprise was also relatively high. As indicated by Maskell (1998), furniture production is an excellent example of a huge and successful export-oriented European low-tech industry, which is mainly located where labour costs are highest.

What is noteworthy is United Kingdom's, on average, third position in the ranking. 
However, interestingly, over the period under study the measure of Hellwig's development model calculated for that country increased from 0.387 to 0.441 , thus making its promotion three places up possible. At that time the United Kingdom was the third biggest furniture manufacturer and the fourth biggest employer in the EU furniture industry. The labour productivity measured with the furniture production value per employee was more-thanone-third higher than the EU average. Higher such values were noted only in Denmark and Germany. The wages of the British market employees were also higher than on the EU furniture market; the wages per employee were almost half higher.

Italy, the EU furniture manufacturer and export leader, scored right after United Kingdom. The measure of Hellwig's development model considering employment and labour productivity increased in the period under study from 0.414 to 0.432 . However, despite the positive trends, the country has dropped from the third to the fourth position. The Italian furniture industry was the third biggest employer; only Poland and Germany employed more people. Interestingly, the three countries provided jobs to more than $40 \%$ of the total number of employees in that industry in the EU and, on top of that, they generated more than $50 \%$ of the values of the furniture production sold. The Italian furniture manufacturers also recorded a relatively high, over-half-higher than the EU average, labour productivity measured with the production value per employee. Only Sweden, Belgium, and Denmark recorded higher values of that indicator. The wages of the Italian furniture enterprise employees were slightly higher that the average wages on the EU furniture market.

The successive ranking positions were as follows: Austria, Sweden, France, Finland and Belgium. It is also worth emphasizing that the top ten countries included only the old EU member countries. Thus, the research results confirm the hypothesis that the new EU member states (EU 13) are characterized by relatively lower labour productivity in the furniture industry than the EU 15 countries. The level of automation in furniture production in the EU13 still differs from Western countries, especially the leading furniture manufacturers and exporters, although in recent years innovation in this area has increased significantly. This means that aspects related to the labour productivity, automation, and digitization of furniture companies in the EU 13 require significant improvement. They can be a potential source to find new competitive advantages in the international market.

Of the EU13 countries, the highest ranking in terms of employment and labour productivity was Poland, one of the top furniture manufacturers and exporters, both on the EU and the global market. Over the study period, it was promoted from the $14^{\text {th }}$ to the $11^{\text {th }}$ position. It means that, despite the crucial role of Poland on the EU job market, as for furniture industry labour productivity, the country was far behind the top manufacturers and exporters, Germany and Italy. Poland's outstanding position among the new member states in terms of employment and labour productivity has been confirmed by Grzegorzewska et al. (2019). Ratajczak (2014) notes that, for many years, the furniture industry has been the driving force of the Polish economy development and enhanced the Polish foreign trade balance. Additionally, the wages of the employees in Poland were more than three-fold lower than the average in the EU old member states. The values of the indicators of the Polish furniture industry considerably different from the reference values include the production value per employee, the number of employees per enterprise and the wages per employee.

After Poland, small EU13 countries (Lithuania, Estonia and Romania), where the furniture industry is essential for the national economy as well as the employer on the job market, were confirmed a considerable share of the furniture industry in the GDP of those 
countries and a considerable share of furniture industry employees, as compared with the total number of industry employees. Neykov et al. (2017) reported similar results that Romania is one of the countries with a high and strategically balanced employment in the wood-based and furniture industries. In addition, production had a major impact on employment or rather on the managerial decisions. Burja and Mărginean (2013) report on the main advantages of the Romanian furniture industry being the availability of raw materials, low labour costs and high technical qualifications. As for Lithuania, Estonia and Romania, similarly as in Poland, there were noted a relatively low labour productivity and low employee wages. Additionally, the share of labour costs in those countries was definitely lower than in the old EU member states. Low labour productivity in most EU13 member states was also confirmed in the latest reports (Žmuk et al. 2018; Herman 2020) and low wages were also noted (Neykov et al. 2017; Herman 2020).

The bottom of the ranking shows Greece, the Czech Republic, Hungary, Bulgaria and Malta; some of the Visegrad Group countries and small countries with the lowest share of employees, as compared with the total number of industry employees. The wages of the employees were more than two-fold lower, and as for Bulgaria, even five-fold lower than the EU average. The problem of low wages in wood-based industry was confirmed by Toth et al. (2019), who stressed that the growth rate of wages is not very high; however, the trend is rising in the long run. Additionally, those countries recorded a more-than-double lower labour efficiency, measured with the production value per employee, and Bulgarian furniture industry noted a more than four-fold lower labour productivity than the EU average, and the productivity was even six-fold lower than in the old EU member states. As indicated by Kupčák and Šmída (2015), the factors affecting the economic results and profitability in wood-processing micro-enterprises include the production capacities, technical and technological standards, and the potential of their further development and the human resources - their quality and management principles, production and business strategies, and the firm's financial situation.

The research has some limitations. K-means cluster analysis requires the number of groups to be defined, although it is usually not known how many groups there are in the set being processed. Moreover, the starting centroids are chosen at random while their selection has a decisive influence on the quality of the resulting clustering. However, it is still one of the most used iterative methods since it is easy to implement. In futures studies, an attempt can be made to use non-hierarchical iterative methods. In addition, the research did not include countries outside the European Union that play an important role in the global furniture industry, i.e. China, USA, Canada, India, etc. In subsequent studies, important furniture manufacturers and exporters from outside the EU should be included. It is planned also to take into account other factors that may affect the level of efficiency in the furniture manufacturing industry and the entire wood-processing industries, e.g. production automation, digitization progress, as well as capital expenditure resulting in the modernization of production and reduction of production costs. 


\section{CONCLUSIONS}

1. The results of the study confirm the spatial variation in employment, labour productivity, and labour costs in the furniture industry in the European Union region. The cluster analysis identified the clusters with the countries similar to one another in terms of employment and labour productivity. It has facilitated determining the greatest competitors for each country in terms of employment and labour productivity.

2. The regions of the most developed EU countries, namely the EU15 countries, report a much higher labour productivity in the furniture industry and offer definitely higher wages than the EU13 countries, which results in a relatively high share of labour costs in production. The top of the ranking shows Germany, Denmark and United Kingdom. As for the new member states, Poland, as one of the leading furniture manufacturers and exporters, both on the EU and global markets, scored highest in terms of employment and labour productivity.

3. For the national economy and the domestic job market, the furniture industry is most important in the countries of Central and Eastern Europe; Lithuania, Estonia and Poland. The lowest labour productivity and the lowest wages were reported for Greece, the Czech Republic, Hungary, Bulgaria, and Malta, and so part of the Visegrad Group countries and small countries with the lowest share of the employees in the total number of industry employees. The employees' wages were more than two-fold lower, and as for Bulgaria, even five-fold lower wages than the EU average.

4. The results of the study can provide a precious source of information for entrepreneurs and managers as they present a multidimensional assessment of the employment structure and labour productivity in the furniture industry in respective countries. They will help the production enterprises identify the areas to be made more efficient, taking important decisions to enhance competitiveness in the sector as well as point a longterm furniture industry development path to the governments under a full EU market integration and internationalisation. It is especially important to ensure a sustainable development of the EU countries.

\section{ACKNOWLEDGMENTS}

The authors are grateful for the support of the National Science Centre Poland, Grant No. 2019/03/X/HS4/01342, Slovak project agency APVV - projects APVV-180520, APVV-18-0378, APVV-17-0456 and APVV-17-0583, agency KEGA - project KEGA $005 T U$ Z-4/2020 and project LignoPro - ITMS: 313011 T720.

\section{REFERENCES CITED}

Azizi, M., Mohebbi, N., and De Felice, F. (2016). "Evaluation of sustainable development of wooden furniture industry using multi criteria decision making method," Ital. Oral Sur. 8, 387-394. DOI: 10.1016/j.aaspro.2016.02.034.

Balicki, A. (2009). Statistical Dimensional Analysis and Its Socio-economic Applications, (Statystyczna analiza wymiarowa i jej zastosowania społeczno-ekonomiczne), 
Gdansk University Publishing House, Gdansk.

Bervidová, L. (2002). "Labour productivity as a factor of sustainable economic development of the CR agriculture," Agric. Econ. 48(2), 55-59.

Barro, R. J. (1991). "Economic growth in a cross section of countries," Q. J. Econ. 106(2), 407-443.

Bozsik, N., and Magda, R. (2018). "Labour productivity in the Hungarian agriculture," Acta Agr. Deb., September, 119-128. DOI: 10.34101/actaagrar/150/1708.

Bumgardner, M., Buehlmann, U., and Koenig, K. (2016). "Investment activities in the U.S. woodworking industry," in: Proceedings of the $20^{\text {th }}$ Central Hardwood Forest Conference; March 28-April 1; Columbia, MO. General Technical Report NRS-P-

167. Newtown Square, PA: U.S. Department of Agriculture, Forest Service, Northern Research Station, 184-191.

Burja, V., and Mărginean, R. (2013). "The furniture industry in Romania and the European Union - A Comparative Approach," Rev. Econ. 65(4), 107-120.

Chobanova, R, and Georgieva, D. (2017). "Women in forestry sector in Bulgaria," in: More Wood, Better Management, Increasing Effectiveness: Starting Points and Perspective, Prague, Czech Republic, pp. 114-121.

Daian, G., and Ozarska, B. (2009). "Wood waste management practices and strategies to increase sustainability standards in the Australian wooden furniture manufacturing sector," J. Clean. Prod. 17, 1594-1602. DOI: 10.1016/j.jclepro.2009.07.008

Dangayach, G. S., and Deshmukh, S. G. (2005). “Advanced manufacturing technology implementation," J. Manuf. Tech. Manag. 16, 483-496.

Feyrer, J. (2008). "Aggregate evidence on the link between age structure and productivity," Popul. Dev. Rev. 34, 78-99.

Frątczak, E., Golata, E., Klimanek, T., Ptak-Chmielewska, A., and Pęczkowski, M. (2009). Multivariate statistical Analysis. Theory and Examples of Applications with the SAS System (Wielowymiarowa analiza statystyczna. Teoria i przykłady zastosowań z systemem SAS), Warsaw School of Economics, Warsaw.

Grzegorzewska, E., and Stasiak-Betlejewska, R. (2014). "The influence of global crisis on financial liquidity and changes in corporate debt of the furniture sector in Poland," Drv. Ind. 65(4), 315-322. DOI: 10.5552/drind.2014.1342.

Grzegorzewska, E., and Więckowska, M. (2016). "Selected aspects of innovation in the furniture industry - Empirical research findings," Drewno 59(198), 147-161. DOI: 10.12841/wood.1644-3985.175.12.

Grzegorzewska, E., Biernacka, J., and Podobas, I. (2019). "Trends in employment and labour productivity in the woodworking industry in selected EU countries," Annals Warsaw Univ. Life Sci. - SGGW. For. Wood Techn. 108, 111-118. DOI: 10.5604/01.3001.0013.7691.

Grzegorzewska, E., Sedliačiková, M., Drábek, J., and Behún, M. (2020). "Evaluating the international competitiveness of Polish furniture manufacturing industry in comparison to the selected EU countries," Acta Fac. Xylologiae Zvolen 62(2), 149164. DOI: 10.17423/AFX.2020.62.2.14

Gumerov, A., Ismagilov, R., Akhmedzyanova, F., and Akhmetov, M. (2020). "Increasing labour productivity at industrial enterprises," The European Proceedings of Social and Behavioural Sciences, International Conference on Economic and Social Trends for Sustainability of Modern Society, DOI: 10.15405/epsbs.2020.10.03.35

Halaj, D., Sedliačiková, M., and Malá, D. (2018). "Customer behavior on the Slovakian roundwood market: A case study," BioResources 13(1), 6003-6020. (DOI: 
10.15376/biores.13.1.6003-6020).

Hall, B. H. (2011). Innovation and Productivity, National Bureau of Economic Research, Working Paper 17178, June 2011, Cambridge.

Han, J. and Kamber, M. (2006). Data Mining: Concepts and Techniques, $2^{\text {nd }}$ Edition, Morgan Kaufmann Publishers, San Francisco.

Han, X., Wen, Y., and Kant, S. (2009). "The global competitiveness of the Chinese wooden furniture industry," For. Policy Econ. 11(8), 561-569. DOI: 10.1016/j.forpol.2009.07.006

Herman, E. (2020). "Labour productivity and wages in the Romanian manufacturing sector," Procedia Manuf., 313-321. DOI: 10.1016/j.promfg.2020.03.046

Hitka, M., and Sirotiakovà, M. (2011). "The impact of economic crisis on the change in motivation of furniture company employees - Case study," Drewno - Wood 54 (185): 119-126.

Hitka, M., Lorincová, S., Ližbetinová, L., Bartáková, G. P., and Merková, M. (2017). "Cluster analysis used as the strategic advantage of human resource management in small and medium-sized enterprises in the wood-processing industry," BioResources 12(4), 7884-7897. DOI: 10.15376/biores.12.4.7884-7897

Hitka, M., Lorincová, S., Gejdoš, M., Klarić K., and Weberová, D. (2019). "Management approach to motivation of white-collar employees in forest enterprises," BioResources 14(3), 5488-5505. DOI: 10.15376/biores.14.3.5488-5505

Horváth, D., and Szabó, R. Z. (2019). "Driving forces and barriers of Industry 4.0: Do multinational and small and medium-sized companies have equal opportunities?" Tech. For. and Social Change 146, 119-132. DOI: 10.1016/j.techfore.2019.05.021.

Hung, M. Ch, Wu, J., Chang, J. H, and Yang, D. L. (2005). "An efficient k-means clustering algorithm using simple partitioning," J. Inf. Sci. Eng. 21, 1157-1177.

Jelačić, D., Faletar, J., and Motik, D. (2020). "Human resource management (HRM) in forest-based industry," in: Management Aspects in Forestry and forest based industries, D. Jelačić (ed.), WoodEMA, Zagreb, pp. 137-152.

Jivkov, V. (2019). "State and trends in the development of the world. European and Bulgarian furniture industries," in: IX International Scientific and Technical Conference Innovations in Forest Industry and Engineering Design - INNO 2018, Innovation in Woodworking Industry and Engineering Design, 1/2019 (15), 7-16.

Karkkainen, L., Kurttila, M., Salminen, O., and Viiri, H. (2014). "Effects of energy wood harvesting on timber production potential and biological diversity in North Karelia," Finland. For. Sci. 60, 1077-1088. DOI: 10.5849/forsci.13-041

Kupčák, V., and Šmída, Z. (2015). "Forestry and wood sector and profitability development in the wood-processing industry of the Czech Republic," J. For. Sci. 61(6), 244-249 DOI: 10.17221/113/2014-JFS

Krueger, A. B., and Lindahl, M. (2001). "Education for growth: Why and for whom?," J. Econ. Lit. 39(4), 1101-1136. DOI 10.3386/w7591

Kukuła, K. (2014). "Zero unitarisation metod as a tool in ranking research," Econ. Sci. Rural Dev. 36, 95-100.

Kukuła, K. (2016). "Municipal waste management in Poland in the light of multidimensional comparative analysis," Oeconomia 15(4), 93-103.

Laleicke, P. (2018). "Wood waste, the challenges of communication and innovation," BioResources 13(2), 2182-2183. DOI: 10.15376/biores.13.2.2182-2183

Landscheidt, S., and Kans, M. (2016). "Automation practices in wood product industries: Lessons learned, current practices and future perspectives," in: The $7^{\text {th }}$ Swedish 
Production Symposium SPS, 25-27 October, Lund, Sweden.

Landscheidt, S., Kans, M., and Winroth, M. (2017). "Opportunities for robotic automation in wood product industries: The supplier and system integrators' perspective," Procedia Manufacturing 11, 233-240. DOI. 1016/j.promfg.2017.07.231

Lieberman, M. B., and Kang, J. (2008). "How to measure company productivity using value-added: A focus on Pohang Steel (POSCO)," Asia Pac. J. Manag. 25(2), 209224. DOI: $10.1007 / \mathrm{s} 10490-007-9081-0$

Lorincová, S., Schmidtová, J., and Javorčíková, J. (2016). "Employee job satisfaction in furniture manufacturing companies in the Slovak Republic," Drvna Industrija 67(4), 351-362. DOI: $10.5552 /$ drind.2016.1614

Malá, D., Sedliačiková, M., and Benčiková, D. (2018). "How customer of small and medium wood-processing Slovak enterprises perceive a green product," BioResources 13(1),1930-1950. DOI: 10.15376/biores.13.1.1930-1950

Maskell, P. (1998). "Low-tech competitive advantages and the role of proximity: The Danish wooden furniture industry," Eur. Urban Reg. Stud. 5, 99-118. DOI: $10.1177 / 096977649800500201$

Merková, M., and Drabek, J. (2010). "Investment and labour productivity growth in wood processing industry in Slovak Republic," Intercathedra 26, 70-75.

Murphy, K., Shleifer, A., and Vishny, R. (1991). "The allocation of talent: Implications for growth," Q. J. Econ. 106(2), 503-530.

Neykov, N., Antov, P., and Dobrev, D. (2017). "Employment rate in wood-processing and furniture industries in the context of European Union enlargement - Comparison between Bulgaria, Romania and Macedonia," Int. J. Wood Design Techn. 6(1), 57-63.

Neykov, N., Antov, P., and Savov, V. (2018). "Sustainable development and forest-based industries: Main considerations and policy measures. The Bulgarian example," Open Economics 1(1), 86-93.

Neykov, N., Kitchoukov, E., Antov, P., and Savov, V. (2019). "Efficiency analysis of the Bulgarian forestry and forest-based industry: A DEA approach," in: International Conference on Innovations in Science and Education, CBU International Conference Proceedings, Prague, Czech Republic 2019, pp. 228-235. DOI: 10.12955/cbup.v7.1366.

Owyong, D. T. (2000). "Productivity growth: Theory and measurement," APO Product. J., 19-29.

Pang, S., H'ng, P., Chai, L., Lee, S., and Paridah, M. T. (2015). "Value added productivity performance of the Peninsular Malaysian wood sawmilling industry," BioResources 10(4), 7324-7338. DOI: 10.15376/biores.10.4.7324-7338

Panytin, A., Tereshchenko, S., Polyanskaya, O., Shaitarova, O., and Mushkarova, O. (2020). "Investment attractiveness of the forest sector in Russian Federation, IOP Conference Series: Earth and Environmental Science, Orlando 2020, pp.1-8. DOI: 10.1088/1755-1315/574/1/012059

Popyk, W., Lis, W., and Mikołajczak, E. (2014). "Innovativeness of wood industry enterprises in the years 2010-2013," Intercathedra 30(3), 110-115.

Potkány, M., Gejdoš, M., and Debnár, M. (2018). "Sustainable innovation approach for wood quality evaluation in green business," Sustainability 10(9), 2984. DOI: $10.3390 /$ su 10092984

Ratajczak, E. (2014). "Polish furniture industry in the light of the concept of smart specialization," Annals Warsaw Univ. Life Sci. - SGGW. For. Wood Techn. 86, 193203. 
Ratnasingam, J., and Ioras, F. (2009). "Foreign direct investment (FDI), added value and environmental-friendly practices in furniture manufacturing: The case of Malaysia and Vietnam," Int. For. Rev.11(4), 464-474.

Ratnasingam, J., Ark, C. K., Mohamed, S., Liat, L. C., Ramasamy, G., and Senin, A. L. (2017). "An analysis of labor and capital productivity in the Malaysian timber sector," BioResources 12(1), 1430-1446. DOI: 10.15376/biores.12.1.1430-1446

Ratnasingam, J., Ab Latib, H., Yi, L. Y., Liat, L. C., and Khoo, A. (2019). "Extent of automation and the readiness for Industry 4.0 among Malaysian furniture manufacturers," BioResources 14(3), 7095-7110. DOI: 10.15376/biores.14.3.70957110

Ratnasingam, J., Yi, L. Y., Abdul Azim, A., Halis, R., Choon Liat, L., Khoo, A., Mat Daud, M., Senin, A. L., Ab Latib, H., Bueno, M. V., Zbiec, M., Garrido, J., Ortega, J., Gómez, M. V., Hashim, R., Zakaria, S., Zainal Abidin, S., and Mat Amin, M. N. Z. (2020). "Assessing the awareness and readiness of the Malaysian furniture industry for Industry 4.0,” BioResources 15(3), 4866-4885. DOI: 10.15376/biores.15.3.48664885

Ratner, B. (2009). "The correlation coefficient: Its values range between $+1 /-1$, or do they?," Journal of Targeting, Measurement and Analysis for Marketing 17, 139-142.

Rogers, M. (1998). The Definition and Measurement of Productivity, Melbourne Institute of Applied Economic and Social Research, The University of Melbourne, Melbourne Institute Working Paper No. 9/98.

Salim, R., Mapulanga, M., Saladi, P., and Karltun, A. (2016). "Automation in the wood product industry: Challenges and opportunities," in: The $7^{\text {th }}$ Swedish Production Symposium SPS, 25-27 October 2016, Lund, pp. 1-5.

Smardzewski, J. (2009). "The Polish furniture industry - A vision of the future," Drewno -Wood 52 (182), 103-114.

Song, L., and AbouRizk, S. M. (2008). "Measuring and modeling labor productivity using historical data," J. Constr. Eng. Manag. 134(10), 786-794.

Stec, M. (2011). "Development conditions of voivodships in Poland - Statistical and econometric analysis (Uwarunkowania rozwojowe województw w Polsce - analiza statystyczno-ekonometryczna)," Social Inequalities and Economic Growth 20, 235238.

Syverson, C. (2010). What Determines Productivity?, Working Paper 15712, National Bureau of Economic Research, Cambridge.

Tan, P.-N., Steinbach, M., and Kumar, V. (2005). Introduction to Data Mining, AddisonWesley.

Toth, D., Maitah, M., and Maitah, K. (2019). "Development and forecast of employment in forestry in the Czech Republic," Sustainability 11(24), 6901. DOI: $10.3390 /$ su 11246901

Van Dalen, H. P., Henkens, K., and Schippers, J. (2010). "Productivity of older workers: Perceptions of employers and employees," Popul. Dev. Rev. 36, 309-330. DOI: 10.1111/j.1728-4457.2010.00331.x

Verkaik, E., and Nabuurs, G. J. (2000). "Wood production potentials of FennoScandinavian forests under nature-orientated management," Scand. J. For. Res. 15, 445-454. DOI: 10.1080/028275800750172673

Wang, L., He, J., and Xu, S. (2017). "The application of Industry 4.0 in customized furniture manufacturing industry," in: $13^{\text {th }}$ Global Congress on Manufacturing and Management (GCMM 2016), Zhengzhou, pp. 30-32. DOI: 
$10.1051 /$ matecconf $/ 201710003022$

Wu, Z. H. (2016). "Manufacturing model of furniture industry in industry 4.0," China For. Prod. Ind. 43(3), 6-10.

Žmuk, B., Dumičić K., and Palić I. (2018). "Forecasting labour productivity in the European Union member states: Is labour productivity changing as expected?," Inter. Descr. Complex Systems 16(3-B), 504-523. DOI: 10.7906/indecs.16.3.20

Article submitted: December 31, 2020; Peer review completed: February 28, 2021; Revised version received and accepted: March 25, 2021; Published: April 1, 2021. DOI: 10.15376/biores.16.2.3643-3661 